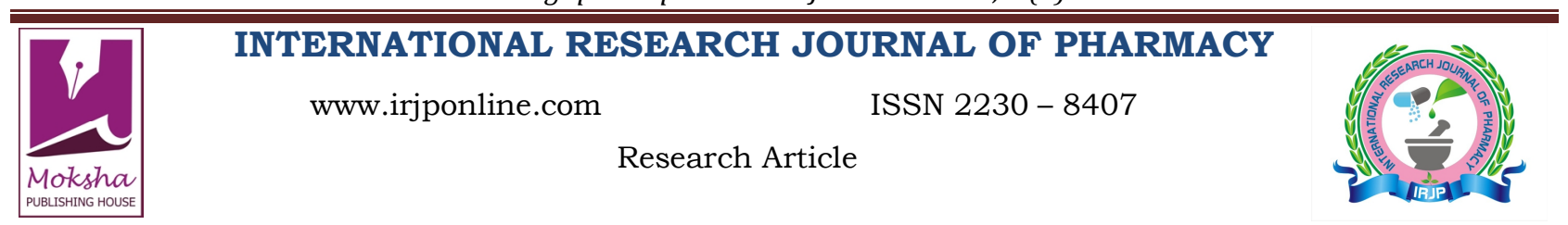

\title{
COMPARATIVE IN VITRO ANTHELMINTIC AND PHYTOCHEMICAL EVALUATION OF METHANOLIC AND PETROLEUM ETHER EXTRACTS OF WOODFERDIA FRUTICOSA (L). FLOWER
}

\author{
Sengupta Rupa* \\ ROFEL, Shri G. M. Bilakhia, College of Pharmacy, Namdha Road, Vapi, Gujarat, India \\ *Corresponding Author Email: rupasengupta222@rediffmail.com \\ Article Received on: 18/05/13 Revised on: 07/06/13 Approved for publication: 11/07/13
}

DOI: $10.7897 / 2230-8407.04735$

IRJP is an official publication of Moksha Publishing House. Website: www.mokshaph.com

(C) All rights reserved.

\begin{abstract}
The present study aims at preliminary phytochemical investigation and anthelmintic activity of dried flowers of Woodfordia fruticosa (L). The dried flowers were extracted individually with methanol and petrolium ether. The extracts were evaluated for phytochemical studies. Preliminary screening of the flowers of Woodfordia fruticosa revealed the presence of carbohydrates, tannins and glycosides in major quantities, phenols in moderate quantities and anthraquinones and flavonoids in minor quantities. Methanol extract and Petrolium ether extract of Woodfordia fruticosa flower were tested for anthelmintic potential against the Indian earth worm Pheritima posthuma. Different concentrations of the extract ranging from $50-100 \mu \mathrm{g} / \mathrm{ml}$ were tested and results expressed as time required for paralysis and death of the worms. Piperazine citrate $(10 \mathrm{mg} / \mathrm{ml})$ and Albendazole $(20 \mathrm{mg} / \mathrm{ml})$ were used as a reference standards and DMSO (1 $\%)$ as the negative control. The methanolic extract of Woodferdia fruticosa (L) flower exhibited significant anthelmintic activity as compared to petroleum ether extract.
\end{abstract}

Keywords: Anthelmintic activity, Woodfordia fruticosa, Pheretima posthuma, Piperazine, Priliminary phytochemical.

\section{INTRODUCTION}

Woodfordia fruticosa is an important traditional medicinal plant belonging to the family Lythraceae. It is extensively used in the preparation of "Ahavas and Arishtas" containing self generated alcohol. The flowers of Woodfordia fruticosa Kurz are commonly used for the treatment of several ailments which includes rheumatism, leucorrhoea, menorrhagia, asthma, liver disorder and inflammatory conditions ${ }^{1}$. The flowers are astringent, acrid, refrigerant, stimulant, depurative, typtic, uterine sedative, antihelmentic, antibacterial and vulnerary, corrective of a pigments, alexeteric and febrifuge. It has antibacterial ${ }^{2}$, antifertility ${ }^{3}$ activities. Moreover it can be used as a mordant in the preparation of dyes ${ }^{4}$. A mixture of Woodfordia fruticosa powder, honey and rice water is extremely affected in diarrhoea, dysentery and piles. It can be safely used even in pregnancy. The decoction of flowers effectively quenches the excessive thirst, especially in diabetic patients ${ }^{5}$. The flowers of this plant have various medicinal uses, possess high content of tannins and have been used as an astringent tonic in disorders of mucous membrane $e^{6,7}$. The powder of dried flowers is sprinkled over ulcers and wounds to diminish discharge and promote granulation ${ }^{8}$. The flowers also showed hepatoprotective activity ${ }^{9}$. The previously isolated constituents from Woodfordia fruticosa flowers are ellagitannin dimmers with astringent and haemostatic properties that affect histamine release ${ }^{10}$. Literature review indicates that anthelmintic activity of the flowers of Woodfordia fruticosa has not been clinically evaluated so far. The present paper reports the preliminary phytochemical screening and anthelmintic activity of methnolic and petroleum ether extracts of the flowers of Woodfordia fruticosa against Earthworms.

\section{MATERIAL AND METHODS \\ Plant Material}

The fresh flowers of Woodfordia fruticosa were collected from Assam in the month of January 2013. The plant were identified and authenticated by a taxonomist and Voucher herbarium specimen was deposited in the Department of Pharmacognosy of ROFEL, Shri G.M.B college of Pharmacy for future reference bearing a No-RPC/RS/009. The plant material was dried in sunlight, pulverized and stored in air tight container and used for further extraction.

\section{Preparation of Extract}

Fifty g of shade dried, powder of flowers of Woodferdia fruticosa Kurz .were extracted successively with $200 \mathrm{ml}$ each of Petroleum ether and Methanol, using a Soxhlet extractor for $48 \mathrm{~h}$ separately. All the extracts were concentrated using rotary flash evaporator. After complete solvent evaporation, each of these solvent extract was weighed and preserved at $5^{\circ} \mathrm{C}$ in an airtight bottle until further use. The percent yield of methanolic extract was $20.8 \% \mathrm{w} / \mathrm{w}$ and petroleum ether $(60$ Grade) extract yield $5.1 \% \mathrm{w} / \mathrm{w}$.

\section{Preliminary Phytochemical Screening}

Chemical tests were carried out on the methanolic and petroleum ether extract using standard procedures to identify the constituents ${ }^{11,12}$. The plant extract was assayed for the presence of alkaloids, flavonoids, tannins, phenolic compounds, saponins, terpenoids, steroids, glycosides,carbohydrates and Proteins or amino acids.

\section{Testing for Alkaloids}

Each extract $(0.5 \mathrm{~g})$ was stirred with $5 \mathrm{~mL}$ of $1 \% \mathrm{HCL}$ on a steam bath. The solution obtained was filtered and one $\mathrm{mL}$ of the filtrate was treated with a few drops of Mayer's reagent. The turbidity of the extract filtrate on addition of Mayer's reagent was taken as evidence of the presence of alkaloids in the extract.

\section{Testing for Tannins and Phenolics}

Each extract $(0.5 \mathrm{~g})$ was separately stirred with $10 \mathrm{ml}$ of distilled water and then filtered. A few drops of $5 \%$ $\mathrm{Fecl}_{3}$ reagent were added to the filtrate. Blue-black or blue green colouration or precipitation was taken as an indication of the presence of phenolics and tannins. 
Test for Saponin

About $2 \mathrm{~g}$ of the powdered sample was boiled in $20 \mathrm{ml}$ of distilled water in a water bath and filtered, $10 \mathrm{ml}$ of the filtrate was mixed with $5 \mathrm{ml}$ of distilled water and shaken vigorously for a stable persistent froth. The frothing was mixed with 3 drops of olive oil and shaken vigorously and observed for the formation of emulsion.

\section{Test for Steroids}

Two $\mathrm{ml}$ of acetic anhydride was added to 0.5 ethanolic extract of each sample with $2 \mathrm{ml} \mathrm{H}_{2} \mathrm{SO}_{4}$. The colour changed from violet to blue or green in some samples indicating the presence of steroids.

\section{Test for Terpenoids (Salkowski test)}

Five $\mathrm{ml}$ of each extract was mixed in $2 \mathrm{ml}$ of chloroform, and concentrated $\mathrm{H}_{2} \mathrm{SO}_{4}(3 \mathrm{ml})$ was carefully added to form a layer. A reddish brown colouration of the inter face formed to show positive results for the presence of terpenoids.

\section{Test for Steroid (Liebermann Burchard Reaction)}

To extract Chloroform, $2 \mathrm{ml}$ acetic anhydride and 2 drops conc. $\mathrm{H}_{2} \mathrm{SO}_{4}$ was added from the side of the test tube. No red or blue colour was appeared indicating the absence of steroids.

\section{Legal's test for Glycosides}

To the hydrolysate $1 \mathrm{ml}$ of pyridine and few drops of sodium nitropruside solution was added and then it was made alkaline with sodium hydroxide solution. Appearance of pink to red colour shows the presence of glycosides.

\section{Borntrager's Test}

Hydrolysate was treated with chloroform and the chloroform layer was separated. To this equal volume of dilute ammonia solution was added. Ammonical layer turned pink colour shows the presence of anthraquinone glycosides.

\section{Test for Carbohydrates (Molisch's test)}

A small quantity of the extract were dissolved separately in 4 $\mathrm{ml}$ of distilled water and filtered. The filtrate was treated with 2-3 drops of $1 \%$ alcoholic alpha nephthol and $2 \mathrm{ml}$ of concentrated sulphuric acid was added along the sides of the test tube. Appearance of brown ring at the junction of the two liquids showed the presence of Carbohydrates.

\section{Test for Amino Acids (Million's test)}

The above prepared mixture was treated with Million's reagent. No red colour formed due to absence of proteins or amino acids.

\section{Screening of Anthemintic Activity Worm Collection and Authentication}

Indian adult earthworms (Pheretima posthuma) were collected from moist soil and water logged areas at Vapi, namdha Road in the rainy season and was identified at the Department of Pharmacology, ROFEL, Shri G.M.B College of Pharmacy. Then all collected worms were washed with normal saline to remove all the faecal matter and used for the anthelmintic study. The earthworms of $4-5 \mathrm{~cm}$ in length and $0.1-0.3 \mathrm{~cm}$ in width were used for all the experimental protocol.

\section{Sample Preparation}

Test sample for in vitro study were prepared by dissolving and suspending $2.5 \mathrm{~g}$ of each extract in minimum amount of DMF and the volume was adjusted to $25 \mathrm{ml}$ with normal saline to obtain a stock solution of concentration of $100 \mathrm{mg} /$ $\mathrm{ml}$. from this stock solution different dilutions were made to get concentration range of 50, 75 and $100 \mathrm{mg} / \mathrm{ml}$.

\section{Drugs and Chemicals}

Piperazine citrate (Glaxo Smithkline), Albendazole (BANDY, Mankind Pharma Ltd., New Delhi, India), Chemicals: Methanol A.R (PCL, Pune, India), DMF (PCL, Pune, India), Saline water (Claris Lifesciences Ltd., Ahmedabad, India).

\section{Anthelmintic Activity}

The anthelmintic activity was performed according to the method of Ajaiyeoba et.al, 2001 ${ }^{13}$. On adult Indian earthworm Pheritima posthuma as it has anatomical and physiological resemblance with the intestinal roundworm parasites of human beings ${ }^{14,15}$. Pheritima posthuma worms are easily available and used as suitable model for screening anthelmintic drugs ${ }^{16}$. Earthworms were divided into nine groups (6 each). The first group (I) served as normal control which received saline water only. The second (II) group received the standard drug Piperazine citrate at a dose level of $10 \mathrm{mg} / \mathrm{ml}$. Groups (III) group received the standard drug Albendazole at a dose level of $20 \mathrm{mg} / \mathrm{ml}$. Groups (IV) to (VI) received doses of Pet. Ether extracts of $50 \mathrm{mg} / \mathrm{ml}, 75$ $\mathrm{mg} / \mathrm{ml}$ and $100 \mathrm{mg} / \mathrm{ml}$, respectively. Groups (VII) to (IX) received doses of methanolic extracts of $50 \mathrm{mg} / \mathrm{ml}, 75 \mathrm{mg} /$ $\mathrm{ml}$ and $100 \mathrm{mg} / \mathrm{ml}$, respectively. Observations were made for the time taken to paralyse or death of individual worms. Paralysis was said to occur when the worms do not revive even in normal saline. Death was concluded when the worms lose their motility followed with fading away of their body colour. Piperazine citrate $(10 \mathrm{mg} / \mathrm{ml})$ and Albendazole $(20$ $\mathrm{mg} / \mathrm{ml}$ ) were used as reference standards and normal saline water as control. All the results were expressed as Mean \pm S.D of six worms in each group.

\section{RESULTS AND DISCUSSIONS}

Preliminary screening of the flowers of Woodfordia fruticosa revealed the presence of carbohydrates, tannins and glycosides in major quantities, phenols in moderate quantities and anthraquinones and flavonoids in minor quantities. Tannins were shown to produce anthelmintic activities. Chemically tannins are polyphenolic compounds. It is possible that tannins contained in the flower extracts of Woodferdia fruticosa produced similar effects. Reported anthelmintic effect of tannins is that they can bind to free proteins in the gastrointestinal tract of host animal or glycoprotein on the cuticle of the parasite and may cause death. The exact mechanism of the anthelminthic activity of Woodferdia fruticosa cannot be explained on the basis of the present result. From the observations made, higher concentration of extract produced paralytic effect much earlier and the time to death was shorter for all worms. While there need further study to isolate and revealed the active constituents responsible for the anthelmintic present in the crude extract of flowers of Woodferdia fruticosa as well as to establish the mechanism of action. 
Table 1: Phytochemical Analysis of Methanolic and Petrolium Ether Extracts of Woodfordia fruticosa Flower

\begin{tabular}{|c|c|c|c|c|}
\hline S. No. & Constituents & Tests & Petrolium Ether Extract & Methanolic Extract \\
\hline 1 & Alkaloids & Mayer's test & ----- & --- \\
\hline 2 & Saponins & Foam test & $\begin{array}{ll}---- \\
--1\end{array}$ & $\begin{array}{ll}---- \\
\end{array}$ \\
\hline 3 & Tanin & Extract $+5 \%$ Fecl3 & & +++ \\
\hline 4 & Terpinoid & Salkowski test & |---------- & ----- \\
\hline 5 & Steroid & Liebermann burchard reaction & ---- & ------ \\
\hline 6 & Glycosides & Legal's test & ++ & +++ \\
\hline 7 & Phenolic compound & Extract $+5 \% \mathrm{Fecl} 3$ & ++ & ++ \\
\hline 8 & Flavanoids & Residue + lead acetate solution & $\begin{array}{ll}--- \\
\end{array}$ & + \\
\hline 9 & Carbohydrats & ---- & ++ & +++ \\
\hline 10 & Amino acids & ------ & $\begin{array}{ll}---- \\
\end{array}$ & --- \\
\hline 11 & Anthraqinones & ------- & & + \\
\hline
\end{tabular}

+++ Major, ++ Moderate, + Traces, - Absence

Table 2: Anthelmintic Activity of Methanolic and Petrolium Ether Extracts of Woodfordia fruticosa Flower

\begin{tabular}{|c|c|c|c|c|}
\hline Test substance & Groups & $\begin{array}{c}\text { Concentration } \\
(\mathbf{m g} / \mathbf{m l})\end{array}$ & $\begin{array}{c}\text { Time taken for paralysis(min.) } \\
(\text { Mean } \pm \text { S.D) }\end{array}$ & $\begin{array}{c}\text { Time taken for Death(min.) } \\
(\mathbf{M e a n} \pm \text { S.D) }\end{array}$ \\
\hline Vehicle & I & ----- & No paralysis (upto72 minutes) & No paralysis (upto72 minutes) \\
\hline Piperazine citrate (Std.) & II & 10 & $21.44 \pm 0.27$ & $60.01 \pm 0.32$ \\
\hline Albendazole (Std.) & III & 20 & $32.86 \pm 0.21$ & $43.50 \pm 0.24$ \\
\hline Methanolic extract & IV & 50 & $22.76 \pm 1.67$ & $44.62 \pm 3.24$ \\
\cline { 2 - 5 } & V & 75 & $16.03 \pm 2.42$ & $26.08 \pm 3.87$ \\
\cline { 2 - 5 } & VI & 100 & $12.07 \pm 1.66$ & $56.33 \pm 1.98$ \\
\hline \multirow{2}{*}{ Petrolium ether extract } & VII & 50 & $26.19 \pm 1.89$ & $48.97 \pm 2.26$ \\
\cline { 2 - 5 } & VIII & 75 & $18.36 \pm 4.06$ & $36.53 \pm 2.54$ \\
\cline { 2 - 5 } & IX & 100 & & \\
\hline
\end{tabular}

Each value represents the mean $\pm \mathrm{SD}(\mathrm{n}=6)$. This activity was Concentration dependent. The potency was found to be inversely proportional to the time taken for paralysis and time of death of the worms

\section{CONCLUSION}

From the above results, it is concluded that Woodferdia fruticosa flower used traditionally to treat intestinal worm infections, showed significant anthelmintic activity. Methanolic extract showed better anthelmintic activity in comparison to the Pet. ether extract of Woodferdia fruticosa flowers. The phytochemical profile showed the presence of carbohydrates, tannins and glycosides in major quantities, phenols in moderate quantities and anthraquinones and flavonoids in minor quantities. Further studies are required to identify the exact chemical constituents present in the flower extracts of this plant responsible for anthelmintic activity.

\section{ACKNOWLEDGEMENT}

The author is thankful to the management of ROFEL, Shri G. M. Bilakhia College of Pharmacy, vapi, Gujarat, India for providing laboratory facilities to carry out the research work.

\section{REFERENCES}

1. Baravalia Yogesh, Vaghasiya Yogesh kumar, Chanda Sumitra. Hepatoprotective effect of Woodfordia fruticosa Kurz. flowers on diclofenac sodium induced liver toxicity in rats. Asian Pacific Journal of Tropical Medicine 2011; 342-346.

2. Parekh J, Chands S. In vitro antibacterial activity of the crude methanol extract of Woodfordia fruticosa Kurz. Flower (Lythraceae), Braz J Microbiol 2007; 38: 204-207. http://dx.doi.org/10.1590/S151783822007000200004

3. Khushalani HN, PA Tatke and Singh KK. Antifertility activity of dried flowers of Woodfordia fruticosa Kurz. Indian J. Pharm. Sci 2006; 68: 528-529. http://dx.doi.org/10.4103/0250-474X.27838

4. Debajit Mahanta and Tiwari. Natural dye-yielding plants and indigenous knowledge on dye preparation in Arunachal Pradesh, northeast India. Current Sci 2005; 88(9): 1474-1479.

5. Paranjpe P. Indian Medicinal Plants- Forgotten Healers, A Guide to Ayurvedic Herbal Medicine, Chaukhamba Sanskrit Pratishthan, New Delhi (India); 2001. PMid:11444804

6. Anjaria J, Parabia M, Dwivedi S. Indian Ethnoveterinary Medicine - An Overview, Pathik Enterprise, Ahmedabad Gujarat, (India); 2002. PMid: 12505048
7. Chopra RN, Nayar SL and Chopra IC. Glossary of Indian Medicinal Plants, Council of Scientific and Industrial Research, New Delhi; 1956. p. 259-265.

8. Krishnan PN, Seeni S. Rapid micropropagation of Woodfordia fruticosa Kurz. Flower (Lythraceae) a rare medicinal plant. Plant Cell Rep 1994; 14: 55-58. http://dx.doi.org/10.1007/BF00233299

9. Chandan BK, Saxena AK, Shukla S, Sharma N, Gupta DK, et al. Hepatoprotective activity of Woodfordia fruticosa Kurz.flowers against carbon tetrachloride induced hepatotoxicity. J Ethnopharmacol 2008; 119: 218-224. http://dx.doi.org/10.1016/ j.jep.2008.06.020 PMid:18639619

10. Yoshida T, Chou T, Haba K, et al. Camelliin B and Nobotanin I, Macrocyclic ellagitannin dimers and related dimers and their antitumor activity. chem pharm bull 1989; 37(11): 3174-3176.

11. Metwally AM, Omar AA, Harraz FM, El Sohafy SM. Phytochemical investigation and antimicrobial activity of Psidium guajava L. leaves. Phcog Mag 2010; 6: 212-8. http://dx.doi.org/10.4103/0973-1296.66939 PMid:20931082 PMCid:PMC2950385

12. Anda SK, Padhi LP, Mohanty G. Antibacterial activities and phytochemical analysis of Cassia fistula (Linn.) leaf. J Adv Pharm Technol Res 2011; 2(1): 62-7. http://dx.doi.org/10.4103/22314040.79814 PMid:22171295 PMCid:PMC3217677

13. Ajayeoba EO, Oncha SA, Olarenwaju OT. In vivo anthelmintic property of Buehholria cariacen and Gyandropis gyancha ext., Pharm Biol 2001; 39: 127-210.

14. Girme AS, Bhalke RD, Ghogare PB, Tambe VD, Jadhav RS, Nirmal SA. Comparative In vitro Anthelmintic Activity of Mentha piperita and Lantana camara from Western India. Dhaka Univ J Pharm Sci 2006; 5: 5-7.

15. Tambe VD, Nirmal SA, Jadhav RS, Ghogare PB, Bhalke RD, Girme AS, Bhamber RS. Anthelmintic activity of Wedelia trilobata leaves. Ind J Nat Prod 22: 27- 29.

16. Dash GK, Sursh P, Sahu SK, Kar DM, Ganpaty S, Panda SB. Evaluation Evolvulus alsinoids Linn. for anthelmintic and antimicrobial activities. J Nat Rem 2002; 2: 182-85.

\section{Cite this article as:}

Sengupta Rupa. Comparative in vitro anthelmintic and phytochemical evaluation of methanolic and petroleum ether extracts of Woodferdia fruticosa (L). flower. Int. Res. J. Pharm. 2013; 4(7):159-161 http:// dx.doi.org/10.7897/2230-8407.04735 